\title{
WATER REGIME CHANGE OF SURFACTANT POLLUTED SOILS
}

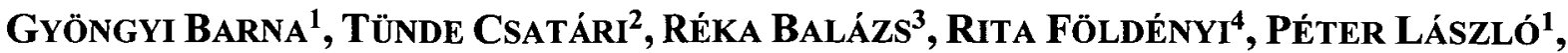 ATTila DUNAI ${ }^{2}$, ANDRÁs MaKó ${ }^{1}$}

\author{
${ }^{1}$ HAS CAR, Institute for Soil Science and Agricultural Chemistry, \\ 1022 Budapest, Herman Ottó str. 15., Hungary; \\ ${ }^{2}$ UP Department of Corp Production and Soil Science, \\ 8360 Keszthely, Deák F. str. 16., Hungary; \\ ${ }^{3} \mathrm{HAS}$ Institute for Geological and Geochemical Research, \\ 1112 Budapest, Budaörsi út 45., Hungary; \\ ${ }^{4}$ UP Department of Earth and Environment Sciences, \\ 8200 Veszprém, Egyetem str10.,Hungary; \\ gyongyi.barna@rissac.hu
}

\begin{abstract}
Studies were made on the adsorption of a cationic surfactant, hexadecylpyridinium-chloride (CPC), on various soils and sediments. The aim was to determine how modify the adsorbed surfactant the soil physical characteristics, mainly water regime.

Water retention were measured, pore size distribution curves were derived from water retention curves, modal suction, total porosity and rate of different pores (macro-, meso-, micro-, ultramicro- and cryptopores) were evaluated. Due to CPC treatment, samples became hydrophobic. Rate of cryptopores declined at all surfactant treated samples, while rate of micropores were raised most of the samples. Except for two samples total porosity was decreased, as well. Kind of these changes can depend on differences in particle size distribution, calcium carbonate content, aggregate.stability, quantity and quality of clay minerals. As pore size changes, amount of retained water also changes.
\end{abstract}

Keywords: soil, surfactant, water regime, pore size distribution

\section{INTRODUCTION}

Surface active agents, surfactants can reach environment mainly through waste water (due to cleaning supplies and detergents), numerous pesticide and fertilizers also contains surfactants as e.g. emulsifiers, wetting agents, adjuvants.

Their other application area is soil and groundwater remediation: depending on the type of pollutants (polar - non-polar) and contamination site (liquid - porous) different kind of surfactants are used (WEST AND HARWELL, 1992; SABATINI ET AL., 1996; SHENG ET AL., 1996; MULLIGAN ET AL., 2001; RASHID ET AL., 2004). In the meantime they can become copollutants (MULLIGAN ET AL., 2001).

Surfactants change several physical, chemical and biological soil properties depends on its type (DOBOZY ET AL., 1970; KUHNT, 1993). They have effects on infiltration, hygroscopicity, porosity (KUHNT, 1993; ABU-ZREIG ET AL., 2003), capillary rise (LAW ET AL., 1966; DOBOZY ET AL., 1970), water retention (KARAGUNDUZ ET AL., 2001), oil retention (CSATÁRI ET AL., 2013), aggregate stability (LAW ET AL., 1966; DOBOZY ET AL., 1970; PICCOLO AND MBAGWU, 1989; MIÓKOVICS ET AL., 2011) and hydraulic conductivity (ALLRED AND BROWN, 1994; RAO ET AL., 2006). They may also affect $\mathrm{pH}$, redox potential, cation exchange capacity (KUHNT, 1993), activity of microorganisms, population composition, cell functions (DoBOzY ET AL., 1970; KUHNT, 1993; BANKS ET AL., 2014).

Pore size distribution curves can be derived from soil water retention curve (SWRC) RAJKAI ET AL. (2015). Modal suction is the matric potential at the peak of the specific 
SWRC. MS corresponds to the most frequent pore size class of the soil. The higher the value of the MS, the smaller the size of the most frequent pores in the soil is.

In this research we measured the water retention capacity of a cationic surfactant treated samples, change in pore size distribution and so in total porosity was detected.

\section{MATERIAL AND METHOD}

The main characteristics of the samples are listed in Table 1, measured by Hungarian standards (BUZÁs, 1993). Particle size distribution was determined according to ISO 11277: 2009(E) method.

Table 1. Characteristics of samples

\begin{tabular}{|c|c|c|c|c|c|c|c|c|c|}
\hline $\begin{array}{l}\text { Sample code and } \\
\text { WRB Soil classification }\end{array}$ & $\begin{array}{l}\text { Clay }+ \\
\mathrm{Fe}(\%)\end{array}$ & $\begin{array}{l}\text { Silt } \\
(\%)\end{array}$ & $\begin{array}{l}\text { Sand } \\
(\%)\end{array}$ & $\begin{array}{c}\text { Humus } \\
(\%)\end{array}$ & $\begin{array}{c}\mathrm{CaCO}_{3} \\
(\%)\end{array}$ & $\begin{array}{l}p H \\
(d w)\end{array}$ & hyl & $\begin{array}{l}C E C \\
\text { (mgeq/ } \\
100 \mathrm{~g})\end{array}$ & $\begin{array}{c}S S A \\
\left(m^{2} / g\right)\end{array}$ \\
\hline $\begin{array}{lcc}(1) & \text { Vertic } & \text { Stagnic } \\
\text { Solonetz } & \text { (clayic) } & \text { (Karcag) }\end{array}$ & 51.09 & 45.90 & 0.88 & 2.00 & 0.13 & 6.92 & 3.90 & 40.85 & 43 \\
\hline $\begin{array}{l}\text { (2) Hortic Terric Cambisol } \\
\text { (Dystric Siltic) A horizon } \\
\text { (Keszthely) }\end{array}$ & 20.99 & 33.13 & 44.28 & 1.55 & 0.05 & 7.04 & 1.24 & 11.84 & 11 \\
\hline $\begin{array}{l}\text { (3) Hortic Terric Cambisol } \\
\text { (Dystric Siltic) B horizon } \\
\text { (Keszthely) }\end{array}$ & 22.89 & 33.87 & 42.29 & 0.94 & 0.00 & 6.83 & 1.49 & 12.38 & 19 \\
\hline $\begin{array}{l}\text { (4) Cutanic Luvisol (Siltic) } \\
\text { A Horizon (Várvölgy) }\end{array}$ & 15.27 & 29.35 & 54.05 & 1.33 & 0.00 & 6.59 & 1.07 & 10.36 & 10 \\
\hline $\begin{array}{l}\text { (5) Cutanic Luvisol (Siltic) } \\
\text { B Horizon (Várvölgy) }\end{array}$ & 22.25 & 26.56 & 50.49 & 0.70 & 0.00 & 6.64 & 1.58 & 12.78 & 20 \\
\hline (6) Quartz sand (Salföld) & & & & & .02 & 7.44 & 0.07 & 0.70 & 1.0 \\
\hline $\begin{array}{lr}\text { (7) Vertic Gleyic } & \text { Luvisol } \\
\text { (Mangani-ferric } & \text { Siltic) } \\
\text { (Magyarzombatfa) } & \\
\end{array}$ & 38.96 & & 34.61 & & 0.00 & 5.74 & 2.22 & 16.78 & 30 \\
\hline (8) Loess (Paks) & & & & & & & 1.02 & 19.74 & .12 .0 \\
\hline $\begin{array}{l}\text { (9) Vermic Calcic } \\
\text { (Anthric } \\
\text { (Kápolnásnyék) }\end{array}$ & 27.60 & 51.68 & 7.50 & 3.70 & 9.52 & 7.83 & 2.25 & 30.25 & 14 \\
\hline $\begin{array}{l}\text { (12) Gleyic Vertisol (Calcic) } \\
\text { (Kisújszállás) }\end{array}$ & 55.01 & 41.19 & 1.05 & 2.76 & 1.10 & 7.51 & 4.49 & 35.69 & 47 \\
\hline
\end{tabular}

The applied cationic surfactant is hexadecylpyridinium-chloride monohydrate, or CPC (Sigma-Aldrich), used mainly in pharmaceutical and cosmetics industry due to its good antibacterial and fungicide properties (HRENOVIC et al., 2008). Its structural formula and other parameters are in Table 2.

Table 2. Major properties of hexadecylpyridinium-chloride monohydrate

\begin{tabular}{|c|c|c|}
\hline Empirical formula & $\mathrm{C}_{21} \mathrm{H}_{38} \mathrm{ClN}^{*} \mathrm{H}_{2} \mathrm{O}$ & \\
\hline Molecular mass $(\mathrm{g} / \mathrm{mol})$ & 358.01 & \\
\hline Water solubility $(\mathrm{g} / \mathrm{l})\left(20^{\circ} \mathrm{C}\right)$ & 50 & $\cdot \mathrm{H}_{2} \mathrm{O}$ \\
\hline Density $\left(\mathrm{g} / \mathrm{cm}^{3}\right)$ & 0.37 & $\stackrel{1}{\mathrm{C}} \mathrm{H}_{2}\left(\mathrm{CH}_{2}\right) \mathrm{O}_{2} \mathrm{O}$ \\
\hline $\mathrm{pH}\left(10 \mathrm{~g} / \mathrm{l}, \mathrm{H}_{2} \mathrm{O}, 20^{\circ} \mathrm{C}\right)$ & $5.0-5.4$ & $\mathrm{CH}_{2}\left(\mathrm{CH}_{2}\right)_{14} \mathrm{C}$ \\
\hline
\end{tabular}

Very few data are available in the literature on the CPC adsorption on real soil (LAW ET AL., 1966; BARNA ET AL., 2015b). The samples were treated with surfactant in the course of 
static equilibrium experiments (FÖLDÉNYI ET AL., 2013). The specific quantity of surfactant required to make the adsorbents hydrophobic was determined based on the adsorption isotherms, assuming that a monomolecular surfactant layer was formed on the surface of the soil particles.

Since we experienced disaggregation and structure failure within the samples following the static equilibrium surfactant treatments we decided to also perform the treatment of samples with distilled water among identical conditions. Comparison of the two type of treatments was done (instead of control samples and surfactant treated).

Water retention capacity measurements were carried out with modified Soilmoisture Equipment Corporation LAB 23 porous ceramic plates, about $90 \mathrm{~cm}^{3}$ artificial soil columns, at three repetitions. Rate of different pores (macro-, meso-, micro-, ultramicroand cryptopores), total porosity were determined. We used grouping system of the SSSA (1997) to classify the pores. Equivalent diameters of the pore classes and corresponding matric potentials $(\log (h) ; \mathrm{cm})$ are as follows: macropores: $>75 \mu \mathrm{m},<1.6 \mathrm{pF}$; mesopores: 30-75 $\mu \mathrm{m}, 1.6-2 \mathrm{pF}$; micropores: 5-30 $\mu \mathrm{m}, 2-2.78 \mathrm{pF}$; ultramicropores: $0.1-5 \mu \mathrm{m}, 2.78-$ $4.47 \mathrm{pF}$ and cryptopores $<0.1 \mu \mathrm{m},>4.47 \mathrm{pF}$ ).

\section{RESULTS}

Due to CPC treatment samples became more hydrophobic, water vapour adsorption was declined, and water retention was decreased (BARNA ET AL., 2015a).

Change in modal suction is presented in Figure 1, either decreases or increases occur. The largest alteration was in case of Magyarszombatfa which has the highest swelling clay minerals content. At sample of Paks changes could be caused by high $(>20 \%)$ calcium carbonate content.

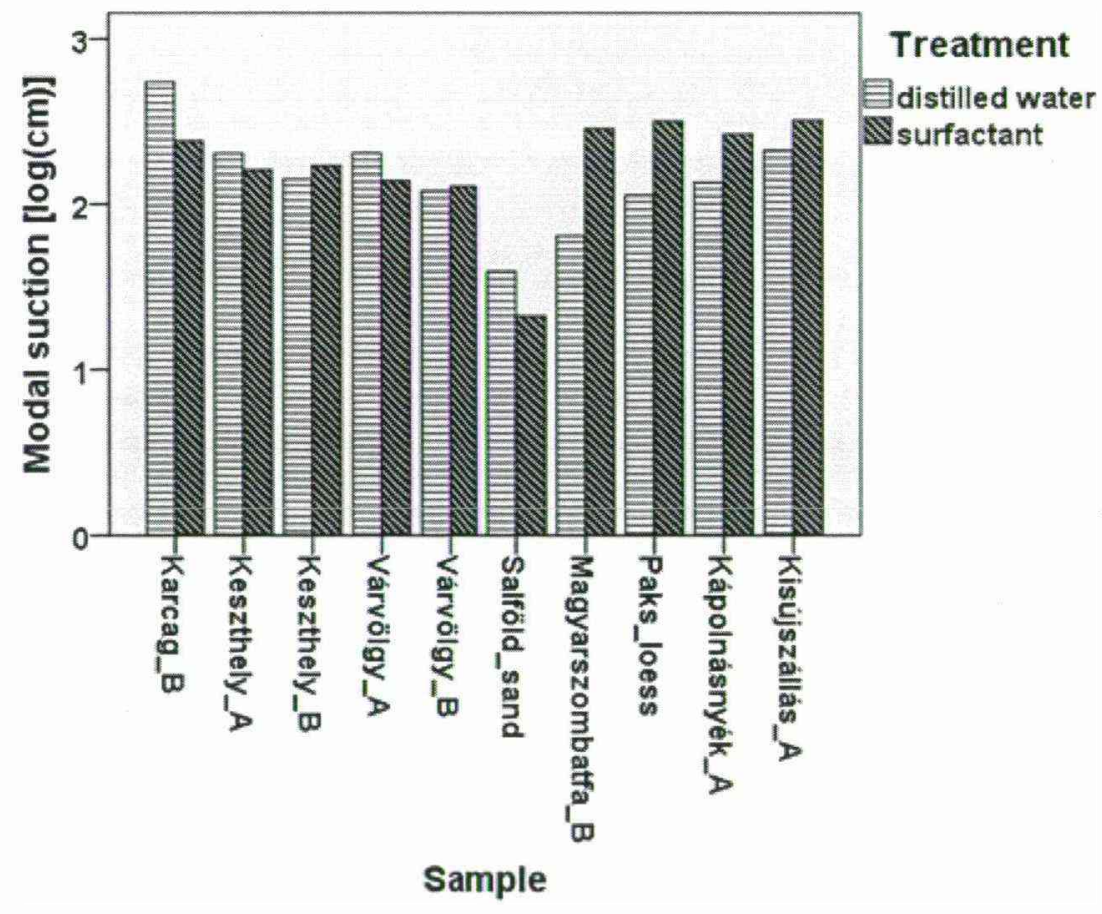

Figure 1. Change in modal suction

Alteration of the different type of pores due to surfactant treatment is shown on Figure 2. Rate of cryptopores declined at all surfactant treated samples, rate of micropores were 
raised most of the samples, except for two samples. Pore size distribution curves become more peaky. At CPC-treated Karcag sample either rate of macro-, meso- and micropores,

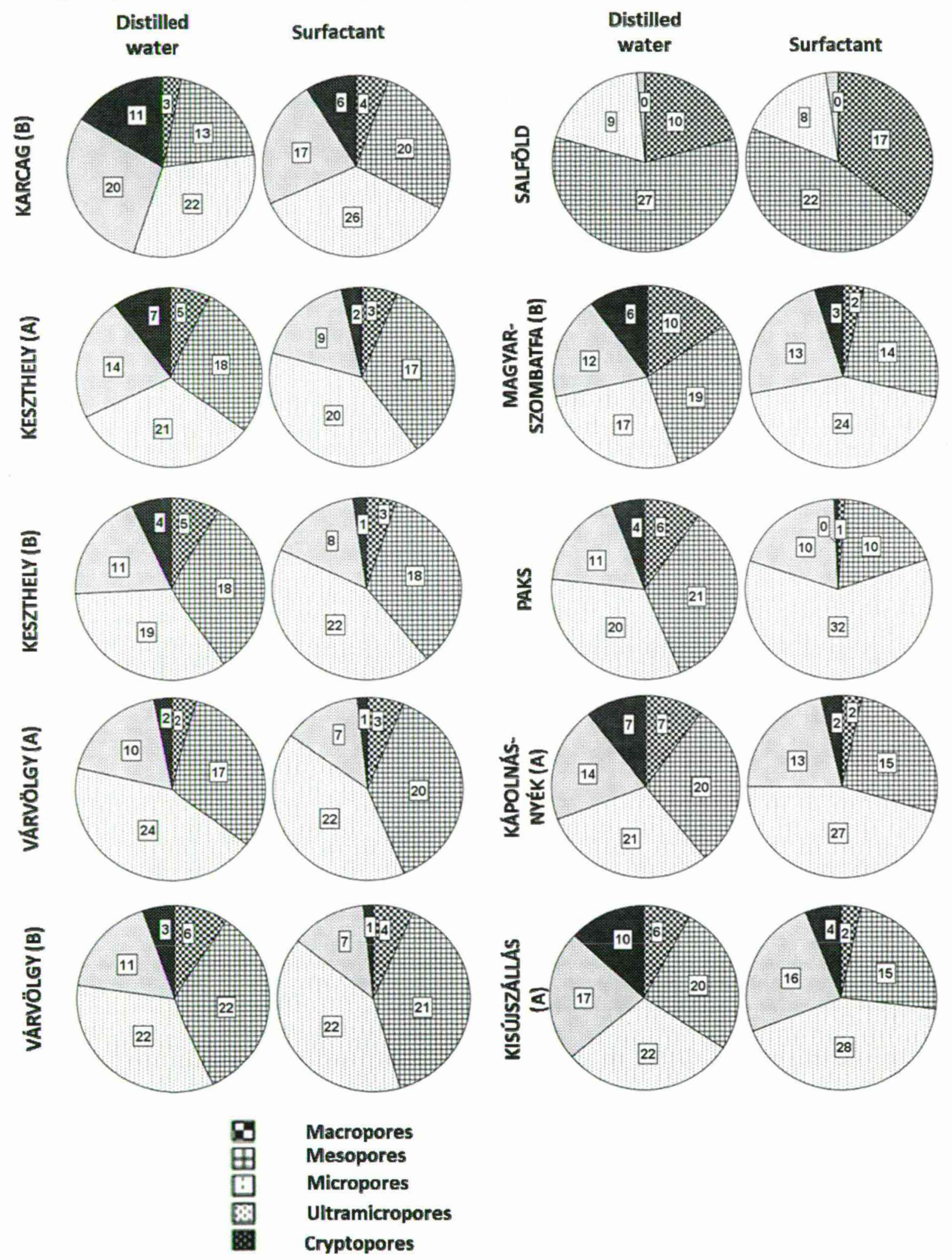

Figure 2. Rate of different pores (in volume\%; amount is total porosity)

or total porosity (TP) became higher. All types of pores were less at Keszthely (A) sample, and TP decreasing was 14\%. Keszthely (B), Paks, Kápolnásnyék and Kisújszállás samples rate of micropores decreased, other pores declined. Macro- and mesopores increased at 
Várvölgy (A). In case of Várvölgy (B) only micropores did not change, the others were declined. Quartz sand sample has bigger pores and rate of macropores became larger, total porosity increased. Micro- and ultramicropores of Magyarszombatfa sample raised up.

\section{CONCLUSIONS}

Due to surfactant treatment samples became more hydrophobic, total porosity was decline. Usually rate of micropores was raised up, the other type of pores mainly decreased. These changes can depend on particle size distribution, aggregate stability, quantity and quality of clay minerals, calcium carbonate content. Surfactant molecules principally bounded to the surface of soil particles in a monolayer which might cause a smaller pore size diameter, as well. Dissolving CPC into the liquid phase can reduce the surface tension that can lead to change in capillary force. Change in pore size and in capillary forces effect the amount of retained water, so water regime.

\section{ACKNOWLEDGEMENTS}

We would like to thank Zoltán Tóth (University of Pannonia) for his help.

Present article was published in the frame of projects TÁMOP-4.2.1/B-09/1/KONV-20100003 and TÁMOP-4.2.2/B-10/1-2010-0025. The projects were realised with the support of the Hungarian Government and the European Union, with the co-funding of the European Social Fund.

\section{REFERENCES}

ABU-ZREIG, M., RUdRA, R.P., Dickinson, W.T. (2003): Effect of application of surfactants on hydraulic properties of soils. Biosystems Engineering 84(3): 363-372.

Allred, B., Brown, G.O. (1994): Surfactant induced reduction in soil hydraulic conductivity. Ground Water Monitoring and Remediation 14: 174-184.

Banks, M.L., Kennedy, A.C., Kremer, R. J., EivaZI, F. (2014): Soil microbial community response to surfactants and herbicides in two soils. Applied Soil Ecology 74: 12-20.

BARNA Gy., FöldÉNYi R., BALÁZs R., DunAi A., MAKó A. (2015a): Egy kationos tenzid megkötődése talajokon és hatása a talajfizikai tulajdonságokra. In: LVII. Georgikon Napok konferencia kiadványa. Keszthely, 2015. X. 1-2. pp. 21-32.

BARNA Gy., FÖldÉNYi R., TÓTH Z., BALÁZS R., MAKÓ A. (2015b): Kationos felületaktív anyag (hexadecilpiridinium-klorid monohidrát) adszorpciója talajokon. Agrokémia és Talajtan 64: 105-122.

BuZÁs I. (szerk.) (1993): Talaj- és agrokémiai vizsgálati módszerkönyv 1-2. Inda 4321 Kiadó. Budapest.

CSATÁri T., MAKó A., Skic, K., TóTH Z., BALÁzS R. (2013): A talajok víz- és szervesfolyadékvisszatartó-képességének változása kationos felületaktív anyaggal történő kezelés hatására. In: Talajvédelem Különszám. 105-114.

DoBozy, O., LAKATOS, M., MÁTÉ, F. (1970): Vlijanyije nyekotorih povernosztno-aktivnih u drugih organicseszkih vescsesztv na fizicsekie szvojsztva pocsvi i razvityije rasztyenyii. Zsurnal Prikladnoj Himii. 43: 639-645.

Földényi R., Tóth Z., Csatári T., Makó A. (2013): Egy kationos tenzid (CPC) adszorpciója talajokon és talajalkotókon. Talajvédelem Különszám. 181-187. 
Hrenović, J., IVAnković, T., SEkovanic, L., Rozic, M. (2008): Toxicity of dodecylpyridinium and cetylpyridinium chlorides against phosphate-accumulating bacterium. Central European Journal of Biology 3: 143-148.

ISO 11277: 2009(E). International Standard. Soil quality - Determination of particle size distribution in mineral soil material - Method by sieving and sedimentation.

Karagunduz, A., Pennel, K.D., Young, M.H. (2001): Influence of a nonionic surfactant on the water retention properties of unsaturated soils. Soil Science Society of America Journal 65: 1392-1399.

KunNT, G. (1993): Behaviour and fate of surfactant in soil. Environmental Toxicology and Chemistry 12: 1813-1820.

LAW, J.P. JR., BloOdWORTh, M.E., RunKLES, J.R. (1966): Reactions of surfactants with montmorillonitic soils. Soil Science Society of America Proceeding 30: 327-332.

Miókovics, E., SzéplÁbi, G., Makó, A., Hernádi, H., Hermann, T. (2011): Effects of surfactants on the aggregate stability of soils. Hungarian Journal of Industrial Chemistry, Veszprém 39(1): 127-131.

Mulligan, C. N., Yong, R. N., GiBBS, B.F. (2001): Surfactant-enhanced remediation of contaminated soil: a review. Engineering Geology 60: 371-380.

Piccolo, A. \& MbagwU, J. S. C. (1989): Effects of humic substances and surfactants on the stability of soil aggregates. Soil Science 147(1): 47-54.

Rajkai, K., Tóth, B., BARna, Gy., Hernádi, H., Kocsis, M., Makó, A. (2015): Particlesize and organic matter effects on structure and water retention of soils. Biologia. 70(11): 1456-1461.

RaO, P-H. He, M., YAnG, X., Zhang, Y-C., Sun, S-Q., WANG, J-S. (2006): Effect of an anionic surfactant on hydraulic conductivities of Sodium- and Calcium-saturated soils. Pedosphere 16(5): 673-680.

RAshid, T., AKBER, A. \& Al-AwAdi, E. (2004): Use of surfactants in enhancing the sorption of petroleum hydrocarbons by natural aquifer materials: a laboratory study. Emigrates Journal for Engineering Research 9: 29-34.

Sabatini, D. A., Knox, R. C. \& Harwell, J. H. (1996): Surfactant-enhanced DNAPL remediation: Surfactant selection, hydraulic efficiency, and economic factors. US EPA. EPA/600/S-96/002.

SHENG, G., XU, S., Boyd, S. A. (1996): Cosorption of organic contaminant from water by hexadecyltrimethyilammonium-exchanged clays. Water Resource 30(6): 1483-1489.

SSSA (1997): Glossary of Soil Science Terms. Soil Science Society of America. Madison. West, C.C., Harwell, H. (1992): Surfactants and surface remediation. Environmental Science and Technology 26(12): 2324-2330. 